NBER WORKING PAPER SERIES

\title{
UNNATURAL SELECTION: PERVERSE INCENTIVES AND THE MISALLOCATION OF CREDIT IN JAPAN
}

\author{
Joe Peek \\ Eric S. Rosengren \\ Working Paper 9643 \\ http://www.nber.org/papers/w9643
NATIONAL BUREAU OF ECONOMIC RESEARCH 1050 Massachusetts Avenue Cambridge, MA 02138
April 2003

We would like to thank Jeremy Stein, David Weinstein, and participants at the NBER Strategic Alliances Conference, the Japan Project meeting in Tokyo, and the American Economic Association meetings for comments on an earlier version of this paper, and Steven Fay for invaluable research assistance. This study is based upon work supported by the National Science Foundation under Grant No. SES-0213967. Any opinions, findings, and conclusions or recommendations expressed in this study are those of the authors and do not necessarily reflect the views of the National Science Foundation, the Federal Reserve Bank of Boston, or the Federal Reserve System. The views expressed herein are those of the authors and not necessarily those of the National Bureau of Economic Research.

C2003 by Joe Peek and Eric S. Rosengren All rights reserved. Short sections of text not to exceed two paragraphs, may be quoted without explicit permission provided that full credit including Cnotice, is given to the source. 
Unnatural Selection: Perverse Incentives and the Misallocation of Credit in Japan

Joe Peek and Eric S. Rosengren

NBER Working Paper No. 9643

April 2003

JEL No.E51, G21

\section{ABSTRACT}

This study examines the misallocation of credit in Japan associated with the perverse incentives of banks to provide additional credit to the weakest firms. Firms are far more likely to receive additional credit if they are in poor financial condition, and these firms continue to perform poorly after receiving additional bank financing. Troubled Japanese banks allocate credit to severely impaired borrowers primarily to avoid the realization of losses on their own balance sheets. This problem is compounded by extensive corporate affiliations, which provide a further incentive for banks to allocate scarce credit based on considerations other than prudent credit risk analysis.

Joe Peek

437C Gatton Business and Economics Building University of Kentucky

Lexington, KY 40506-0034

jpeek0@uky.edu
Eric S. Rosengren

Supervision and Regulation Department, T-10 Federal Reserve Bank of Boston 600 Atlantic Avenue

Boston, MA 02106-2076

Eric.Rosengren@bos.frb.org 


\section{Unnatural Selection: Perverse Incentives and the Misallocation of Credit in Japan}

The severe economic crisis in Japan, associated with the collapse of the Japanese stock and real estate markets and the dramatic deterioration in the health of the Japanese banking sector, represents one of the major economic events of the late twentieth century. It is even more striking because the second largest economy in the world remained stagnant for more than a decade, and even today shows no evidence of returning to the robust health that characterized most of its postwar history. This study investigates an important contributing factor to this economic malaise: the misallocation of credit by banks. Japanese banks have incentives to continue making credit available to the weakest firms, many of which are already insolvent, insulating those firms from market forces that otherwise would force the restructuring or bankruptcy of those firms.

Bank regulation and supervision policies in Japan provide banks that have significant nonperforming loans and impaired capital little incentive to be strict with troubled borrowers. In fact, it is in the self-interest of banks to follow a policy of forbearance with their problem borrowers in order to avoid pressure on the banks to increase their own loan loss reserves, further impairing their capital. This leads to a policy of banks "evergreening" loans, whereby a bank extends additional credit to a troubled firm to enable the firm to make interest payments on outstanding loans and avoid or delay bankruptcy. By keeping the loan current, the bank's balance sheet looks better, since the bank is not required to report such problem loans among its nonperforming loans. Although banks have the incentive to evergreen loans, their ability to aggressively pursue such policies requires government complicity. Our evidence is consistent with the government being unwilling to force recognition of asset quality problems in bank portfolios in an attempt to limit costly bailouts of the banking sector and additional firm closures. 
Using detailed data on loans from individual lenders to individual firms, we show that the misallocation of bank credit reflects a general problem with the incentives of banks to continue lending to their most troubled borrowers. Additional credit is far more likely for deeply troubled firms, which perform poorly after receiving additional credit. Furthermore, banks with reported capital ratios close to their required ratios are even more likely to make loans to the weakest firms. This misallocation of credit is far less prevalent for lenders without strong corporate affiliations with borrowers, as well as for nonbank lenders relative to banks. While resolving this misallocation of credit requires realization of losses at banks and sales in already depressed markets, it does not require a complete realignment of the industrial organization of Japan that would be needed if the problem were due primarily to corporate affiliations rather than misaligned incentives for banks.

The rest of the study is as follows. The next section provides some background on the role of banks in allocating credit in the Japanese economy. The second section discusses the perverse incentives affecting bank lending behavior. The third section describes the data and empirical results. The final section provides our conclusions.

I. The role of banks in allocating credit in Japan

Banking relationships in Japan are far more important than in the United States. While the U.S. is characterized as a market-centered economy, Japan is considered to be a bankcentered economy. Japanese firms rely more on bank debt than firms in the United States, although bond financing in Japan has become increasingly important over the past decade (Hoshi and Kashyap 1999). But the differences go deeper than simply the relative importance of relationship versus arm's length financing in the two countries. The relationships between banks 
and firms in Japan are much stronger, being characterized by main bank relationships, as well as, in many instances, additional ties arising from the lending bank being in the same keiretsu group as the firm. Furthermore, Japanese capitalism differs from the style prevalent in the United States, especially when it comes to the allocation of credit. For example, many bank lending decisions are guided by the perceived national duty of banks to support troubled firms, rather than being a result of the careful credit risk analysis that would dominate the decision were a profit maximization motive the primary consideration. ${ }^{1}$

The firm-main bank relationship in Japan is solidified in a number of ways. The main bank takes primary responsibility for monitoring the firm and can serve as a form of corporate governance (Kaplan and Minton 1994). The main bank is particularly important during times of distress, when it can require changes in the affiliated firm's management and alter its board of directors (Kang and Shivdasani 1995; Morck and Nakamura 1999). This oversight provided by the bank can reduce typical information asymmetries, resulting in firms having greater access to external credit, which, in turn, affects firms' investment decisions (Hoshi, Kashyap and Scharfstein 1991). However, there is a dark side to this close lending relationship: If the bank rather than the borrower becomes troubled, the ability of the firm to finance investment may be impeded (Gibson 1995; Kang and Stultz 2000; Klein, Peek and Rosengren 2002).

During the 1980s and early 1990s, most studies of Japanese bank-firm affiliations have found significant benefits. These studies emphasized the unique features of Japanese bank affiliations that reduced agency costs (Hoshi, Kashyap, and Scharfstein 1993; Hoshi, Kashyap, and Scharfstein 1990). Banks with intertwined business relationships, shareholding relationships, board of directors relationships, and financing relationships with their loan customers should have substantially more information about those firms than do external 
monitors. Furthermore, to the extent that a firm's main bank or members of its keiretsu would be willing to provide backup financing should the firm become financially troubled, firms were able to maintain a higher ratio of bank debt relative to their total assets. However, the benefits of close firm-main bank ties may be limited. For example, while Weinstein and Yafeh (1998) find that a close relationship with a firm's bank increases the availability of credit, this does not lead to higher profitability or growth for the firm, perhaps because the bank discourages the firm from investing in high risk, high expected return projects, or because the bank extracts all the rents.

More recently, studies have been more critical of the close affiliations of Japanese banks with their borrowers, viewing such affiliations as a problem that has contributed to a decade of subpar economic growth, rather than as an alternative market model (Kang and Stultz 2000; Morck and Nakamura 1999). In particular, if the primary role of bank affiliations is to insulate management from market forces by enabling firms to avoid the discipline that can be provided by external creditors and investors, this limiting of outside corporate governance would manifest itself as a misallocation of credit.

The puzzling response of banks to the capital crisis

As banks came under increasing pressure in meeting capital ratio requirements during the 1990s, they faced difficult choices about how best to shrink their balance sheets. One option is for banks to shrink their foreign operations, which will typically affect foreign borrowers with a weaker banking relationship than is typical of long-standing domestic borrowers. Indeed, this seems to be the path initially followed by Japanese banks beginning in the early 1990s (Peek and Rosengren 1997, 2000). Although the domestic Japanese economy was insulated from declining bank loans initially, domestic bank loans began to decline by the mid 1990s. ${ }^{2}$ 
To the extent that the deteriorating health of Japanese banks during the 1990s impaired their ability to satisfy the credit needs of their loan customers, one might expect that many firms would rely increasingly on alternative sources of credit. In particular, one might expect to observe an acceleration of the shift to bond finance that had occurred in response to the easing of government restrictions on the ability of Japanese firms to issue bonds that began in the mid1970s (Hoshi and Kashyap 2001). However, the shift to bond finance and away from bank finance by Japanese firms did not continue during the 1990s, even as the bad loan problems at banks intensified.

Table 1 presents information on the extent to which Japanese firms that are listed on either the first or second section of the Tokyo stock exchange rely on bonds and loans to finance their operations. The numbers in the table are the mean values for each liability category calculated as a percent of firm assets for each year of our 1993 to 1999 sample period. One of the more striking results in the table is that during this time of severe problems in the banking sector, firms systematically decreased their reliance on bonds as a share of their assets. Given the stagnation of the Japanese economy during the 1990s, one might easily attribute this decline to a weakening of the demand for credit by firms. However, during the 1993 to 1997 period, the general declines in the firms' loans-to-assets ratios were less pronounced, and, from 1997 to 1999, the loans-to-assets ratios actually rose markedly, reaching levels exceeding their 1993 values, even as firm reliance on bond finance continued its decline.

One possible explanation for the shift from bond finance to bank finance by many firms at a time when banks were under severe pressure from the deteriorating quality of their loan portfolios is that banks were attempting to increase the quality of their loan portfolios by increasing their exposure to firms that had performed well enough to enter the bond market. In 
particular, by using the superior information acquired from main bank and keiretsu affiliations with the firms, banks could "cherry pick" among the better quality firms that had access to the bond market. If so, then one would expect that the set of firms obtaining additional bank loans would tend to outperform the average firm.

The results in Table 2 address the relationship between a firm obtaining increased bank finance and its subsequent performance. For this test, the dependent variable is the percent change in the firm's stock price from period $t$ to period $t+1$. The set of explanatory variables includes $(0,1)$ dummy variables that have a value of one if the lender category increased loans to the firm during the previous year, that is, from period t-1 to period t. The specifications also include a set of annual time dummy variables to control for average changes in stock prices and the general macroeconomy from year to year, as well as a set of industry dummy variables to control for differences across industries.

The first column of Table 2 contains the results for the relationship between an increase in total loans to a firm and the subsequent change in the firm's stock price for annual stock price changes for the 1994-98 period. The observations in this panel dataset are at the firm level, with loans to a given firm from all lender types aggregated across lenders so that there is one observation per firm per year. Row 1 indicates that an increase in total loans to a firm is associated with a decline in the firm's stock price of about three-quarters of a percent during the subsequent year, although it is not statistically significant. Column 2 presents estimates of the stock price equation for the 1996-98 period, when a larger proportion of the banks were under severe pressure to improve the quality of their loan portfolios. The estimated coefficient in column 2 is now three times as large as in column 1, and statistically significant. Thus, during this subperiod, an increase in total loans to a firm is associated with a decline in the firm's stock 
price of about 2.4 percent during the subsequent year, after controlling for the average change in stock prices. Furthermore, the significant negative estimated coefficient indicates that any positive bias embedded in the estimated coefficient associated with a firm's subsequent performance being improved by access to additional credit is overcome.

The results in column 3 are more to the point with respect to affiliated lenders possibly exploiting access to superior information about affiliated firms to identify those with the best prospects when making decisions to increase loans. The estimated coefficients for main banks indicate an increase in loans by these banks is associated with a subsequent decline in firm stock prices in excess of 3 percent. The estimated effect for main banks in the same keiretsu as the firm is somewhat larger, and both estimated coefficients are statistically significant. The estimated effects for secondary lenders are much weaker, as would be expected. The estimated decline associated with increased loans from secondary banks in the same keiretsu as the firm is less than half that for main banks and is not significant. The estimated coefficient for nonaffiliated secondary banks is actually positive, although it is not significant. These results are not consistent with banks picking winners, perhaps by exploiting superior information in order to direct lending to those firms with the best prospects. Rather, it appears that banks were basing their lending decisions on supporting troubled firms, many of which may have been returning to bank (relationship) credit as they were priced out of the (arms length) bond market.

\section{Perverse incentives associated with the banking crisis}

The primary hypothesis investigated in this study is that it is in the self-interest of banks to follow a policy of forbearance with their problem borrowers in order to avoid having to report impaired loans as nonperforming. The bank can avoid a mandatory increase in its reported 
nonperforming loans as long as it makes sufficient credit available to the firm to enable it to make interest payments on the outstanding loans from the bank and to avoid declaring bankruptcy. ${ }^{3}$ Consequently, a bank may continue lending to troubled firms to provide sufficient financing to keep otherwise economically bankrupt firms afloat. This "evergreening" of loans benefits the firm because it can avoid (or at least delay) bankruptcy. It also enables the bank to avoid (or delay) a further increase in its reported nonperforming loans, so that the bank does not have to make additional loan charge offs and loan loss provisions, which would reduce the bank's earnings, and thus capital. Such practices, particularly during a time of reduced bank lending, would appear as increases in loans to the most troubled firms. ${ }^{4}$ And, given the low interest rate environment in Japan, it does not require substantial amounts of new credit to enable troubled firms to make their interest payments so as to remain alive.

Japanese banks also may be responding to significant government pressure to avoid a credit crunch or a precipitous decline in economic conditions that might occur if they were to reduce credit to troubled firms. The government, faced with a growing budget deficit and a voting public weary of funding bank bailouts, may prefer banks to continue their policies of forbearance in order to avoid the alternative scenario of massive firm, and perhaps bank, failures and, in particular, the associated costs, both financial and political. ${ }^{5}$ The lack of transparency and the use of accounting gimmicks allowed bank supervisors to implement forbearance policies that allowed banks to understate their problem loans and overstate their capital so that they appeared to be sufficiently capitalized. ${ }^{6}$

This discussion suggests several related hypotheses about Japanese bank lending behavior during the 1990s. The "evergreening" hypothesis is that Japanese banks acted in their own self interest by making additional loans to weak firms to avoid having to declare existing 
loans as nonperforming. This hypothesis would be supported by evidence that weaker firms were more likely to obtain additional loans. ${ }^{7}$ The "balance sheet cosmetics" hypothesis is that the incentive for a bank to make additional credit available to troubled firms to which the bank already has loans outstanding increases as the bank's reported risk-based capital ratio nears its required capital ratio. That is, it is the appearance rather than the reality of adequate capital that is important, even though it is widely believed that Japanese bank capital ratios are substantially overstated. ${ }^{8}$ This hypothesis can be tested by examining the extent to which a bank became more likely to increase loans, especially to the weakest firms, as its reported risk-based capital ratio approached its capital requirement. Such behavior would be in sharp contrast to the typical response of troubled U.S. banks that shrank their loan portfolios in order to increase their (riskbased) capital-to-assets ratio. Finally, we test the "affiliation" hypothesis that corporate affiliations, in the form of main bank and same-keiretsu ties, increase the likelihood that a bank will increase loans, with the probability being greater the weaker the affiliated firm.

The basic equation for the hypothesis tests provides estimates for the contributions of bank and firm health to the probability that a bank increases credit to a firm, controlling for other firm and bank characteristics, using the following logit equation:

$$
\begin{aligned}
& \operatorname{Pr}\left(\operatorname{LOAN}_{\mathrm{i}, \mathrm{j}, \mathrm{t}}\right)=\mathrm{a}_{0}+\mathrm{a}_{1} \text { FIRM }_{\mathrm{i}, \mathrm{j}, \mathrm{t}-1}+\mathrm{a}_{2} \text { BANK }_{\mathrm{i}, \mathrm{j}, \mathrm{t}-1}+\mathrm{a}_{3} \mathrm{CAPREQ}_{\mathrm{i}, \mathrm{t}, \mathrm{t}-1}+\mathrm{a}_{4} \mathrm{AFFIL}_{\mathrm{i}, \mathrm{j}, \mathrm{t}-1}+ \\
& \mathrm{a}_{5} \operatorname{TIME}_{\mathrm{i}, \mathrm{j}, \mathrm{t}}+\mathrm{u}_{\mathrm{i}, \mathrm{j}, \mathrm{t}}
\end{aligned}
$$

The dependent variable has a value of one if loans to firm $i$ by bank $j$ increased from year $t-1$ to year $t$, and zero if the bank's loans to firm i were unchanged or decreased from year $t-1$ to year $t$. Thus, for a given firm (i), the regression sample will contain in each year (t) one observation for 
each bank (j) from which the firm borrows in that year. We focus on increases in loans, since that requires the lender to take action. The reasons underlying a decline in loans outstanding to a firm are much more heterogeneous, since such an outcome could result passively from the amortization of an outstanding loan or the loan maturing, as well as from a lender making the decision to call a loan, to refuse to renew a loan, or even to forgive a loan.

FIRM is a vector of variables intended to capture firm health and other characteristics of the firm that are unrelated to its corporate affiliations with lenders, including controlling for loan demand. The variables considered include the firm's return on assets (FROA) during the prior year, the percent change in the firm's equity price over the prior year (FPCPR), the firm's liquid assets as a percent of its total assets (FLIQA) for the prior year, and the percent change in the firm's sales (FSALES) over the prior year. ${ }^{9}$ We also control for other firm characteristics by including the logarithm of the firm's total real assets (FLASSET), a set of $(0,1)$ dummy variables indicating whether a firm just entered the bond market (FENBMKT), is in the bond market (FINBMKT), or just left the bond market (FEXBMKT), and a set of nine industry dummy variables. While the set of industry dummy variables should help control for shifts in loan demand at a more aggregated level, the set of dummy variables for a firm entering, exiting, or being in the bond market should help control for shifts in loan demand at the individual firm level.

BANK is a vector of variables intended to capture bank health. These variables include the percent change in the bank's equity price over the past year (BPCPR), the bank's risk-based capital ratio (BRBC), and the bank's nonperforming loans as a percent of its total assets (BNPLA). The reported regressions focus on BPCPR, which dominated the other two measures. ${ }^{10}$ 
The CAPREQ vector includes measures related to the deviation of a bank's reported riskbased capital ratio from its required capital ratio. As a bank's reported capital ratio approaches its required capital ratio, the bank comes under more pressure to avoid or delay having additional loans being declared as nonperforming. Thus, the bank has an even stronger incentive to evergreen loans to its current customers. Two risk-based capital thresholds are considered that allow for a differential effect when a bank's reported capital ratio is near its required capital ratio. REQ1 is a $(0,1)$ dummy variable that has a value of one if the bank's risk-based capital ratio is less than 1 percentage point above the bank's required capital ratio. REQ2 is a $(0,1)$ dummy variable that has a value of one if the bank's risk-based capital ratio is between 1 and 2 percentage points above the bank's required capital ratio. Each bank's required capital ratio is based on its classification as an international ( 8 percent), a domestic (4 percent), or a "switcher" bank by Montgomery (2001).

In addition to including REQ1 and REQ2 individually, the CAPREQ vector also includes REQ1 and REQ2 each interacted with the three measures of firm health: FROA, FLIQA, and FSALES. While REQ1 and REQ2 allow for differential effects emanating from a bank being close to its required capital ratio, the interaction terms allow for any enhanced incentive that banks have to make additional loans to a firm based on the firm's health. It should be noted that the estimated coefficients will be biased against a finding of evergreening, insofar as the test relies on reported capital ratios that are known to be an overstatement of the underlying economic capital ratios. The estimated coefficients measure a differential effect relative to all other banks, even though we know that many of the banks with reported capital ratios that are more than 2 percentage points above their required capital ratio are economically undercapitalized. 
AFFIL is a vector of six variables reflecting group affiliations. MBANK is a $(0,1)$ dummy variable that has a value of one if the bank is the firm's main bank. The next two variables reflect the strength of the main bank tie and the health of the firm's main bank. MBLFD is measured as main bank loans to the firm as a percent of the firm's total debt. MBPCPR is the percent change in the equity price of the firm's main bank over the prior year. The other three variables are related to a firm's keretsu ties. SAMEK is a $(0,1)$ dummy variable that has a value of one if the lender is in the same keiretsu as the firm. KEIR is a $(0,1)$ dummy variable that has a value of one if the firm is in one of the eight bank-centered financial (horizontal) keiretsus (Mitsubishi, Mitsui, Sumitomo, Fuyo, Dai-Ichi Kangyo, Sanwa, IBJ and Sakura), and zero otherwise. PK is the percent ownership of the firm by keiretsu members among the top ten equity holders. We also include a set of annual time dummy variables to capture the effects of the macroeconomy. These annual dummy variables will capture the average effect of economic conditions in each year.

\section{Data and Empirical Results}

We use a rich panel data set to examine bank lending patterns in order to determine how Japanese banks reacted to the economic problems in the 1990s, and how these reactions affected credit availability to Japanese firms. By using Japanese firm-level data, we are able to link individual Japanese firms to their individual lenders. This linking of individual lenders to individual borrowers is critical for understanding how bank lending behavior can affect the real economy. Such a link cannot be made clearly in many other countries, such as the United States, where bank-borrower relationships are considered private information. 
For our tests, we use annual data for 1993 through 1999. The starting date of our sample corresponds to when the Basle Accord risk-based capital requirements were fully implemented in Japan. We then focus on the rest of the decade as banks came under increasing pressure to maintain capital ratios above minimum capital requirements. To investigate the factors that impact how banks allocate credit across firms, we examine the pattern of loans obtained by all firms included in the Pacific-Basin Capital Market Databases (PACAP), which includes all firstand second-section firms that are traded on the Tokyo stock exchange. The PACAP database includes the balance sheet and income statements of firms based on their fiscal year-end reports. Bank capital and nonperforming loan data are obtained from Bankscope, produced by FitchIBCA. The data for loans outstanding to individual firms from each lender are obtained from the Nikkei Needs database, with loan reporting based on the firm's fiscal year.

To avoid timing problems, we limit our sample to those firms with a fiscal year that ends in March, which is by far the date most commonly used by Japanese firms, as well as corresponding to the March balance sheet and income reports by banks. We identify each firm's main bank as the first listed reference bank in the Japan Company Handbook. The identification of keiretsu membership and the share of ownership of keiretsu firms among their top 10 equity holders by firms in the same keiretsu are obtained from Industrial Groupings in Japan: The Anatomy of the Keiretsu by Dodwell Marketing Consultants.

Table 3 contains the means, standard deviations, minimum values, and maximum values for the explanatory variables in the base regression for the set of observations for loans from market-traded banks. Those variables, both individually and interacted with the REQ1 and REQ2 dummy variables, are used to obtain the results contained in Table 4 from estimating the logit specification shown in equation 1. Because including aggregate regressors in the equation, 
such as the set of annual time dummy variables, suggests a likely correlation among regression errors within a particular year, we compute robust coefficient standard errors that allow for dependence of regression errors within years. As discussed above, the dependent variable is a $(0,1)$ dummy variable having a value of one if the bank increased lending to the firm, and zero otherwise.

The estimates in Table 4 provide evidence on the evergreening and balance sheet cosmetics hypotheses. The first column is based on the panel of firm-lender observations that includes all first- and second-section firms on the Tokyo stock exchange and market-traded banks for which all required data are available. The second column contains the results for the same specification as column 1 , but with the observations with extreme values excluded from the sample. ${ }^{11}$ The estimated coefficients are quite similar across the two specifications, indicating that the results are robust, insofar as they are not sensitive to observations with extreme values. ${ }^{12}$

The coefficient estimates provide evidence of the perverse relationship between the probability of increased bank loans and firm health. The negative and highly significant coefficients on FROA and FLIQA indicate that the weaker is a firm's health, the more likely it will receive additional bank loans, consistent with the evergreening hypothesis. On the other hand, FSALES has significant positive coefficients, likely indicating that firms with stronger sales growth also have stronger loan demand.

Consistent with the balance sheet cosmetics hypothesis, both REQ1 and REQ2 have estimated coefficients that are positive and highly significant. Banks with reported capital ratios close to their required ratios are more likely to increase loans to firms, with the estimated coefficients on REQ1 being larger than those on REQ2, as expected. Furthermore, for the full sample, the estimated coefficients on FROA and FLIQA interacted with REQ1 and REQ2 are 
each negative, with REQ1*FLIQA and REQ2*FLIQA being significant at the 5 percent level, and REQ1*FROA being significant at the 10 percent level, indicating that the perverse relationship with weaker firm performance being associated with a higher probability of increased loans from banks is even stronger for those banks with reported capital ratios near the required capital thresholds. For the sample omitting the observations with extreme values, the estimated coefficient on REQ1*FROA is significant at the 5 percent level, while those on REQ1*FLIQA, REQ2*FLIQA, and REQ2*FSALES are significant at the 10 percent level.

Thus, the evidence presented in this table provides strong evidence consistent with the evergreening hypothesis, insofar as firms with a lower return on assets and weaker liquidity are more likely to obtain additional bank loans. The evidence is also consistent with the balance sheet cosmetics hypothesis, insofar as those banks with reported capital ratios close to their required minimums are more likely to increase credit to firms, with somewhat weaker evidence that they are more likely than other banks to increase credit to firms the weaker is firm health. Furthermore, that BPCPR, our measure of bank health, does not have a significant effect again indicates that it is maintaining the appearance of adequate capital, rather than the bank's actual economic health, that affects its lending behavior.

The results also indicate that corporate affiliations may be important. The estimated coefficients on MBANK, PK, and SAMEK are each statistically significant in both specifications, while that for MBLFD is significant in the second column. The estimated coefficients on PK, the percent ownership of the firm by other members of its keiretsu among the firm's top ten equity holders, are negative, indicating that the more closely the firm is tied to its keiretsu affiliates through equity ownership, the less likely are banks to increase loans to the firm. This result might reflect keiretsu firms relying more heavily on other keiretsu members to 
provide financing during difficult times, perhaps through trade credit from suppliers or from nonbank lenders. The positive coefficients on MBANK and SAMEK indicate that firms are more likely to get additional loans if the bank is their main bank and/or in the same keiretsu as the firm. The positive coefficient on MBLFD, main bank loans to the firm as a percent of the firm's total debt, indicates that the firm is more likely to get additional loans from banks the greater the exposure of the main bank to the firm.

This raises the question of the extent to which corporate affiliations between banks and their borrowers magnify the evergreening behavior of banks. To the extent that lenders feel an obligation to come to the aid of affiliated troubled firms, main banks and same-keiretsu lenders may have additional incentives to keep weak or insolvent firms alive. However, the direction of the same-keiretsu effect is ambiguous, insofar as a same-keiretsu main bank might reduce its exposure to the firm (or increase it by less) while other members of the keiretsu shouldered more of the burden of the bailout. In that case, secondary banks and nonbanks in the same keiretsu as the firm would tend to increase the availability of credit to the firm in order to offset the increased exposure of the main bank that otherwise would occur. In this way, even secondary banks in the same keiretsu as the firm might feel added pressure to make credit available to troubled firms. In contrast, one might expect the absence of corporate affiliations to allow secondary lenders not in the same keiretsu as the firm to base their lending decisions on the prospects of the borrowing firm, so that their lending would be positively related to firm health. However, to the extent that nonaffiliated lenders are subjected to pressure from either the government or the firm's main bank (as organizer of support for a troubled firm) to participate in any firm rescue, nonaffiliated lenders may still aid such firms, although any correlation between increased lending and deteriorating firm health would be weaker than for affiliated lenders. 
By allowing for differential effects for main banks and for same-keiretsu relationships, we can deduce whether these affiliations magnify the tendency for banks to increase loans the more troubled is a firm. To test this affiliation hypothesis, the base specification is extended to include differential effects emanating from corporate affiliations in the following manner:

$$
\begin{gathered}
\operatorname{Pr}\left(\text { LOAN }_{\mathrm{i}, \mathrm{j}, \mathrm{t}}\right)=\mathrm{b}_{0}+\mathrm{b}_{1} \text { FIRM }_{\mathrm{i}, \mathrm{j}, \mathrm{t}-1}+\mathrm{b}_{2} \text { BANK }_{\mathrm{i}, \mathrm{j}, \mathrm{t}-1}+\mathrm{b}_{3} \mathrm{CAPREQ}_{\mathrm{i}, \mathrm{j}, \mathrm{t}-1}+\mathrm{b}_{4} \mathrm{AFFIL}_{\mathrm{i}, \mathrm{j}, \mathrm{t}-1}+ \\
\mathrm{b}_{5} \mathrm{MB}^{*} \mathrm{X}_{\mathrm{i}, \mathrm{j}, \mathrm{t}-1}+\mathrm{b}_{6} \mathrm{SK}^{*} \mathrm{X}_{\mathrm{i}, \mathrm{j}, \mathrm{t}-1}+\mathrm{b}_{7} \mathrm{TIME}_{\mathrm{i}, \mathrm{j}, \mathrm{t}}+\mathrm{u}_{\mathrm{i}, \mathrm{j}, \mathrm{t}}
\end{gathered}
$$

In order to isolate the differential effects of corporate affiliations, we include two sets of interaction terms, one for main bank ties $(\mathrm{MB} * \mathrm{X} 1)$ and one for keiretsu ties $\left(\mathrm{SK}^{*} \mathrm{X} 2\right)$. The interactive variables for the main bank ties are interacted with MBANK, the $(0,1)$ dummy variable that has a value of one if the bank is the firm's main bank. The differential effects of keiretsu ties are obtained by using SAMEK, the $(0,1)$ dummy variable that has a value of one if the lender is in the same keiretsu as the firm. The variables in the set of interaction terms include those in the base specification that are intended to measure strength of affiliation, firm health, and bank health. The set of main bank interaction variables (X1) include MBANK, in addition to MBANK interacted with each of the following measures: SAMEK, KEIR, PK, MBLFD, FROA, FLIQA, FSALES, and BPCPR. The set of keiretsu interaction variables (X2) includes SAMEK, in addition to SAMEK interacted with the following variables: PK, MBLFD, MBPCPR, FROA, FLIQA, FSALES, and BPCPR. Note that we did not include both BPCPR and MBPCPR in the set of main bank interaction variables, since once they are multiplied by MBANK, the two interactive variables are identical. Similarly, SAMEK is not interacted with KEIR, since SAMEK and SAMEK*KEIR are perfectly collinear. 
With this specification, the base group of lenders is secondary banks that are not members of the same keiretsu as the firm. This includes all observations of firms that are not members of a keiretsu, as well as all observations of loans to a firm by lenders that are either in a different keiretsu or not members of a keiretsu. The estimated coefficients on the interactive terms are then interpreted as measures of the extent to which lending by the firm's main bank or by banks in the same keiretsu as the firm responds differently than is the case for nonaffiliated lenders to measures of the strength of affiliations, firm health, and bank health.

Table 5 contains the estimated coefficients for the expanded specification. The estimated coefficients for the variables in the base specification shown in Table 4 are essentially unchanged when the additional main bank and same-keiretsu interactive variables are added to the specification. The two additional sets of estimated coefficients indicate the differential responses of main banks (the interactive variable names that begin with $\mathrm{MB}$ ) and of banks in the same keiretsu as the firm (the interactive variable names that begin with SK) measured relative to secondary banks not in the same keiretsu as the firm.

It is still the case that main banks and banks in the same keiretsu are more likely to provide additional loans to affiliated firms. However, if the main bank is in the same keiretsu as the firm, that is, MB*SAMEK has a value of one, the bank is slightly less likely than main banks not in the same keiretsu $(0.781$ vs. $0.653=0.781-0.629+0.501)$ to provide additional credit to the firm, perhaps because the firm has a network of other keiretsu members from which it is able to obtain any required additional credit. Consistent with this story, SK*PK has a significant negative estimated coefficient in each column, indicating that banks in the same keiretsu as the firm are less likely to extend additional loans to the firm the larger the share of the firm owned by its keiretsu members. 
We next focus on the extent to which affiliated banks respond differently to firm health than do nonaffiliated banks. The estimated coefficients on MB*FROA are negative and significant at the 5 percent level, while those for MB*FLIQA are significant at the 10 percent level, indicating that main banks are even more likely to extend additional credit to the weakest firms, compared to nonaffiliated lenders. This is consistent with main banks feeling a stronger obligation to come to the aid of their troubled firms than is the case for nonaffiliated secondary lenders. For same-keiretsu lenders, only SK*FSALES has a significant negative effect, indicating that same-keiretsu banks are more likely to provide additional loans to firms the weaker is their sales growth. Interestingly, the weaker is bank health, as measured by the percent change in the bank's stock price (BPCPR), the more likely (relative to nonaffiliated banks) are both main banks and banks in the same keiretsu to provide additional loans to affiliated firms.

The results in Table 5 indicate that corporate affiliations tend to magnify the extent to which banks evergreen loans, although the stronger are the ownership ties of other keiretsu members to the firm (PK), the less likely it is that banks will increase lending to the firm. This is consistent with keiretsu members having access to alternative financing through affiliated suppliers, customers, and nonbank lenders, such as life insurance companies, as discussed above. To further investigate the role of corporate affiliations on lending behavior, we expand the sample of lenders to include nonbank financial firms, such as insurance companies, and government-controlled banks in addition to the market-traded banks that formed the sample for the previous tables. This allows us to isolate the extent to which bank lending behavior differs from that of other types of lenders. As with the sample of bank lenders, we differentiate between nonbank financial firms that are and are not in the same keiretsu as the firm. Table 6 contains the results for this specification, with each column in the table containing the estimated effects 
for one of the seven lender categories. These distinctions are important, since they provide insights into how nonbank keiretsu members might support troubled firms, how governmentcontrolled banks might support troubled firms, and whether nonbank lenders not in the same keiretsu as the firm differ in the degree to which they support troubled firms.

The results for the three firm health proxies are of particular interest, since they indicate a strong and widespread inverse relationship between firm health and the likelihood of obtaining additional loans. All seven of the estimated coefficients on FROA are negative, with six being significant. It is striking that the lone exception is for nonbank lenders not in the same keiretsu as the firm, the lender type with the weakest incentive to aid a distressed firm. In fact, the estimated coefficient is about one-third the value of the next lowest estimated effect, that for government-controlled banks, and one-sixth that for main banks.

Main banks have the strongest estimated inverse relationship, presumably because of their strong ties to the firm and their obligation to come to the aid of troubled firms for which they serve as a main bank. However, even secondary banks display this inverse relationship. The point estimates indicate that secondary banks in the same keiretsu as the firm are slightly more likely to increase loans to the firm compared to secondary banks not in the same keiretsu as the firm, although the difference is not statistically significant. The extent to which even secondary banks are more likely to make credit available to the weakest firms is consistent with reports of government pressure on banks to support troubled firms to prevent a credit crunch or an even sharper rise in firm bankruptcies. In fact, government-controlled banks also are more likely to increase loans to firms with the lowest return on assets.

Finally, the difference between the responses of nonbank financial lenders that are and are not in the same keiretsu as the firm is quite striking. The same-keiretsu effect is strong, 
although the estimated effect is slightly less than that for secondary banks in the same keiretsu, perhaps because nonbanks are not under as much government pressure as are banks to support troubled firms. Strikingly, for nonbank lenders not in the same keiretsu as the firm, the least affiliated lender category, FROA has an estimated coefficient that is only about one-fourth the size of that for nonbank lenders in the same keiretsu, and that estimated coefficient, alone among all the lender types, is not statistically significant. Thus, there is no evidence that a nonaffiliated nonbank lender feels an obligation to support troubled firms by being more likely to increase loans to the weakest firms.

The results for FLIQA are similar to those for FROA. All seven estimated coefficients are negative, with all but that for nonbanks not in the same keiretsu being significant. Thus, lenders are more likely to increase loans to the firms with the weakest liquidity position. This effect is strongest for main banks not in the same keiretsu as the firm. The effect is somewhat weaker for main banks in the same keiretsu, both types of secondary banks, and governmentcontrolled banks. While still statistically significant, the estimated effect for nonbanks in the same keiretsu as the firm is about one-third as large as that for main banks not in the same keiretsu. Finally, while the effect for nonbank lenders not in the same keiretsu is of the same magnitude as that for nonbanks in the same keiretsu as the firm, the effect is not statistically significant. The estimated coefficients for FSALES are mostly positive, but only two are significant. It is likely that the positive effects are a consequence of loan demand being positively correlated with sales growth.

The estimated coefficients for the other explanatory variables are consistent with the results in Tables 4 and 5. The positive coefficients on KEIR suggest that a firm benefits from being in a keiretsu in terms of obtaining credit, even from lenders outside the firm's keiretsu. 
The estimated coefficients on PK are consistently negative, with six of the seven effects being significant, indicating that the larger the share of the firm owned by its other keiretsu members, the less likely are these lenders to increase lending to the firm, other things equal. The positive estimated coefficients on MBLFD suggests that secondary banks may feel that loans to firms whose main banks have a large exposure are less risky, insofar as the main bank is more likely to bailout the firm, and thus other lenders, if the firm's health deteriorates substantially. The significant negative estimated coefficients on MBPCPR indicate that both nonbank lenders in the same keiretsu as the firm and government-controlled lenders may be supporting firms with troubled main banks.

The results in Table 6 make four key points. First, there is widespread evergreening of loans by banks, with banks being more likely to increase loans to a firm the weaker is the firm's health. Lenders appear to be meeting some obligation, perceived or imposed, to support troubled firms, rather than allocating credit in a way that directs loans primarily to those firms with the best prospects. This is true even for nonaffiliated secondary banks, perhaps due to pressure from main banks on other lenders to participate proportionately in any bailout of a troubled firm, pressure from the government for banks to support troubled firms, or some combination of such pressures. Second, corporate affiliations, in the form of main bank or keiretsu ties, make it even more likely that a lender will increase loans to a firm the weaker is that firm's health. Third, government-controlled banks also are more likely to increase loans to a firm the weaker is the firm's health. Furthermore, in addition to this direct assistance to troubled firms, governmentcontrolled banks provide indirect support of troubled main banks, insofar as governmentcontrolled banks are more likely to increase loans to a firm the weaker is the health of the firm's main bank. Finally, the results indicate the extent to which nonaffiliated nonbanks may apply 
different criteria than other lenders in deciding to supply additional credit to firms. Other things equal, the weaker is a firm's health, as measured either by its return on assets or by its liquidity, nonbanks not in the same keiretsu as the firm are not more likely to increase loans to the firm, in sharp contrast to each of the other categories of lenders. Thus, nonaffiliated nonbank lenders appear to be different from these other lender types, insofar as they do not appear to have the same incentives or pressures to evergreen loans.

\section{Conclusions}

This study empirically investigates how banks responded to incentives to increase loans to severely impaired firms, even if the firms were not economically viable and the loans were unlikely to be profitable to the lender. Some of these incentives were internal to the banks, emanating from financially weak banks attempting to limit the growth in reported problem loans on their balance sheets in order to maintain required capital ratios, as well as perceived obligations to come to the aid of firms affiliated with the bank through either main bank or keiretsu relationships. Other incentives were external to the banks, emanating from government pressure on banks to continue lending to financially weak firms in order to avoid an even larger surge in unemployment and firm bankruptcies, as well as limiting the financial costs associated with massive bank bailouts or failures. The political concerns associated with having to deal with the official recognition that the banking system was severely undercapitalized and the consequences of banks severely limiting credit to troubled firms provided bank supervisors with the incentive to continue their forbearance policies toward banks. The continuing lack of transparency and the use of accounting gimmicks allowed the forbearance policies to be implemented. In particular, banks were allowed to understate their nonperforming loans and 
make loan loss provisions that were insufficient, resulting in bank income, and thus bank capital, being overstated, allowing banks to continue to appear to be sufficiently capitalized. ${ }^{13}$

In particular, we test three specific hypotheses: (1) that banks acted in their own self interest by evergreening loans to the weakest firms; (2) that balance sheet cosmetics were important, insofar as the incentive for banks to evergreen loans increased as their reported capital ratio approached their required capital ratio; and (3) that corporate affiliations had the effect of increasing the availability of loans to affiliated firms, insulating those firms from market discipline, rather than directing credit to firms with the best prospects as affiliated lenders exploited the superior information obtained from that affiliation. The empirical results provide strong support for each of these three hypotheses. Banks have practiced the evergreening of loans, particularly if the bank had a reported capital ratio close to its required capital ratio and particularly to affiliated borrowers. It also appears that Japanese banks may have been responding to government pressure to avoid a credit crunch or a precipitous decline in economic activity by extending credit to troubled firms. However, in sharp contrast to banks, nonaffiliated nonbanks do not appear to have had the same incentives to engage in the widespread evergreening of loans.

Just as forbearance by bank regulators has allowed the banks to be slow to restructure, bank support for troubled and noncompetitive firms has prevented the needed restructuring of nonfinancial firms. Thus, while the evergreening of loans in Japan insulated many severely troubled Japanese firms from market forces and may have prevented a bank capital crunch, that behavior nonetheless exacerbated economic problems for the economy by promoting the allocation of an increasing share of bank credit to many of the firms least likely to use it productively. To the extent that banks reacting to perverse incentives led to credit being 
allocated to firms with poor prospects, the economic recovery would be hampered. Thus, by insulating troubled (and perhaps insolvent) firms from market forces that would force either a major restructuring or bankruptcy of the firms, the misallocation of credit would severely hinder the economic recovery and prolong the malaise, consistent with the lost decade of the 1990s. Furthermore, such a misallocation of credit, by inhibiting the needed restructuring of the economy, would adversely impact the long-run growth prospects of the Japanese economy. 


\section{REFERENCES}

Dvororak, Phred. 2001. “Japan's Banks Face Debate on What Counts as Capital." The Wall Street Journal, November 20, C1.

Gibson, Michael S. 1995. "Can Bank Health Affect Investment? Evidence from Japan.” Journal of Business, 68, July, 281-308.

Hall, Brian J. and David E. Weinstein. 2000. "Main Banks, Creditor Concentration, and the Resolution of Financial Distress in Japan." In Masahiko Aoki and Gary R. Saxonhouse, eds., Finance, Governance, and Competitiveness in Japan. New York: Oxford University Press, 6480 .

Hoshi, Takeo and Anil Kashyap. 1999. "The Japanese Banking Crisis: Where Did It Come From and How Will It End?" in Ben Bernanke and Julio Rotemberg, eds., NBER Macroeconomics Annual 1999. Cambridge: MIT Press.

Hoshi, Takeo and Anil Kashyap. 2001. Corporate Financing and Governance in Japan. Cambridge, MA: The MIT Press.

Hoshi, Takeo, Anil Kashyap and David Scharfstein. 1990. "The Role of Banks in Reducing the Costs of Financial Distress in Japan.” Journal of Financial Economics, 27, 67-88.

Hoshi, Takeo, Anil Kashyap and David Scharfstein. 1991. "Corporate Structure, Liquidity, and Investment: Evidence from Japanese Industrial Groups." Quarterly Journal of Economics, 106, 33-60.

Hoshi, Takeo, Anil Kashyap and David Scharfstein. 1993. "The Choice Between Public and Private Debt: An Analysis of Post-Deregulation Corporate Financing in Japan." Manuscript.

Kang, Jun-Koo and Anil Shivdasani. 1995. "Firm Performance, Corporate Governance, and Top Executive Turnover in Japan.” Journal of Financial Economics, 38, 29-58.

Kang, Jun-Koo and Anil Shivdasani. 1997. "Corporate Restructuring During Performance Declines in Japan.” Journal of Financial Economics, 46, 29-65.

Kang, Jun-Koo and Rene M. Stultz. 2000. Do Banking Shocks Affect Borrowing Firm Performance? An Analysis of the Japanese Experience.” Journal of Business, 73, 1-23.

Kaplan, Steven N. and Bernadette Minton. 1994. "Appointments of Outsiders to Japanese Corporate Boards: Determinants and Implications for Managers." Journal of Financial Economics, 36, 225-58.

Klein, Michael W., Joe Peek, and Eric S. Rosengren. 2002. "Troubled Banks, Impaired Foreign Direct Investment: The Role of Relative Access to Credit." The American Economic Review, June, forthcoming. 
Milhaupt, Curtis J. 2001a. "Creative Norm Destruction: The Evolution of Nonlegal Rules in Japanese Corporate Governance.” University of Pennsylvania Law Review, 149, 2083-2129.

Milhaupt, Curtis J. 2001b. “On the (Fleeting) Existence of the Main Bank System and Other Japanese Economic Institutions." The Center for Law and Economic Studies, Columbia University, Working Paper No. 194, November.

Miwa, Yoshiro and J. Mark Ramseyer. 2001a. "The Fable of the Keiretsu.” The Harvard John M. Olin Center Discussion Paper No. 316, March.

Miwa, Yoshiro and J. Mark Ramseyer. 2001b. "The Myth of the Main Bank: Japan and Comparative Corporate Governance." The Harvard John M. Olin Center Discussion Paper No. 333, September.

Montgomery, Heather. 2001. "The Effect of the Basel Accord on Bank Portfolios in Japan." Manuscript presented at NBER Japan Group meeting, Tokyo, September.

Morck, Randall and Masao Nakamura. 1999. "Banks and Corporate Control in Japan." Journal of Finance, 54, 319-39.

Morck, Randall, Masao Nakamura, and Anil Shivdasani. 2000. "Banks, Ownership Structure and Firm Value in Japan." Journal of Business, 73, 539-67.

Peek, Joe and Eric S. Rosengren. 1997. "The International Transmission of Financial Shocks: The Case of Japan." The American Economic Review, 87, September, 495-505.

Peek, Joe and Eric S. Rosengren. 2000. "Collateral Damage: Effects of the Japanese Bank Crisis on Real Activity in the United States." The American Economic Review, 90, March, 3045 .

Peek, Joe and Eric S. Rosengren. 2001. "Determinants of the Japan Premium: Actions Speak Louder Than Words.” Journal of International Economics, 53, 285-305.

Petersen, Mitchell A. and Raghuram G. Rajan. 1994 "The Benefits of Lending Relationships: Evidence from Small Business Data." Journal of Finance, 49, March, 3-38.

Pilling, David. 2002. “Japanese Banks in 'Intensive Care,' says FSA.” Financial Times, April 13-14.

Singer, Jason and Phred Dvorak. 2001. "Shinsei Bank Pressured to Keep Shakey Loans." The Wall Street Journal, September 26, C1.

Tett, Gillian and David Ibison. 2001. "Tokyo 'May Have to Support Banks'.” Financial Times, September 14. 
The Economist. 2001. "Mere Fiddling." June 30, 69.

The Economist. 2002a. "Surreal." April 20, 74.

The Economist. 2002b. “Nationalized Once, Nationalized Again?” July 6, 71.

Weinstein, David E. and Yishay Yafeh. 1995. "Japan's Corporate Groups: Collusive or Competitive? An Empirical Investigation of Keiretsu Behavior.” Journal of Industrial Economics, 43, December, 359-76.

Weinstein, David E. and Yishay Yafeh. 1998. "On the Costs of a Bank-Centered Financial System: Evidence from the Changing Main Bank Relations in Japan." Journal of Finance, 53, 635-72. 
Table 1

Bonds and Loans as a Percent of Assets, Mean Values

\begin{tabular}{|c|c|c|c|c|c|c|c|}
\hline & 1993 & 1994 & 1995 & 1996 & 1997 & 1998 & 1999 \\
\hline Bonds & 10.12 & 10.17 & 9.73 & 8.67 & 8.38 & 7.34 & 7.11 \\
\hline Loans & 18.44 & 18.72 & 18.64 & 17.95 & 17.46 & 17.83 & 19.87 \\
\hline Bank Loans & 15.03 & 15.25 & 15.28 & 14.87 & 14.58 & 14.83 & 16.55 \\
\hline Main Bank Loans & 4.46 & 4.56 & 4.65 & 4.52 & 4.51 & 4.74 & 5.43 \\
\hline
\end{tabular}

\section{Table 2}

Loan Increases and the Subsequent Change in Stock Prices

Ordinary Least Squares Estimation

Total Loans

\begin{tabular}{lll}
\hline $1994-98$ & $1996-98$ & $1996-98$ \\
\hline-0.775 & $-2.433^{* *}$ & \\
$(1.224)$ & $(0.760)$ & \\
& & $-3.463^{*}$ \\
& & $(1.390)$ \\
& & $-3.042^{* *}$ \\
& & $(1.011)$ \\
& & -1.489 \\
& & $(2.060)$ \\
4783 & & 0.684 \\
0.422 & 2887 & $(1.158)$ \\
& 0.478 & 2887 \\
& & 0.479
\end{tabular}

Notes: Each equation also includes a set of annual time dummy variables and a set of industry dummy variables. Below each estimated coefficient, we report the associated robust standard error calculated by relaxing the assumption of independence of the errors for a given year.

* Significant at the 5 percent level.

** Significant at the 1 percent level. 
Table 3

Descriptive Statistics for Regressors, Market-Traded Bank Sample, 1993-99

\begin{tabular}{lcccc}
\hline \hline \multirow{2}{*}{ KEIR } & Mean & Std Dev & Min & Max \\
\cline { 2 - 5 } PK & 0.513 & 0.500 & 0 & 1 \\
\hline MBLFD & 12.073 & 16.443 & 0 & 88.300 \\
\hline MBPCPR & 7.135 & 6.435 & 0 & 75.265 \\
\hline FROA & -7.283 & 23.862 & -55.915 & 57.783 \\
\hline FLIQA & 2.842 & 2.923 & -18.644 & 24.022 \\
\hline FSALES & 34.061 & 15.082 & 0.823 & 96.198 \\
\hline BPCPR & 1.708 & 10.230 & -82.763 & 155.572 \\
\hline MBANK & -7.464 & 22.871 & -64.746 & 128.835 \\
\hline SAMEK & 0.073 & 0.260 & 0 & 1 \\
\hline FLASSET & 0.066 & 0.249 & 0 & 1 \\
\hline FENBMKT & 7.356 & 1.513 & 2.750 & 11.202 \\
\hline FINBMKT & 0.014 & 0.118 & 0 & 1 \\
\hline FEXBMKT & 0.731 & 0.443 & 0 & 1 \\
\hline \hline
\end{tabular}




\begin{tabular}{|c|c|c|}
\hline \multicolumn{3}{|l|}{$\begin{array}{l}\text { Table } 4 \\
\text { The Effects of Evergre } \\
\text { Logit Specification }\end{array}$} \\
\hline 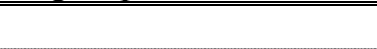 & Full Sample & Extreme Observations Eliminated \\
\hline FROA & $\begin{array}{l}-0.053^{* *} \\
(0.010)\end{array}$ & $\begin{array}{l}-0.059^{* *} \\
(0.010)\end{array}$ \\
\hline FLIQA & $\begin{array}{l}-0.011^{* *} \\
(0.002)\end{array}$ & $\begin{array}{l}-0.011^{* *} \\
(0.002)\end{array}$ \\
\hline FSALES & $\begin{array}{l}0.008^{* *} \\
(0.002)\end{array}$ & $\begin{array}{l}0.010^{* * *} \\
(0.001)\end{array}$ \\
\hline REQ1 & $\begin{array}{l}0.352 * * \\
(0.122)\end{array}$ & $\begin{array}{l}0.360^{* *} \\
(0.128)\end{array}$ \\
\hline REQ2 & $\begin{array}{l}0.231^{* *} \\
(0.071)\end{array}$ & $\begin{array}{l}0.217^{* *} \\
(0.072)\end{array}$ \\
\hline REQ1*FROA & $\begin{array}{l}-0.027 \\
(0.014)\end{array}$ & $\begin{array}{l}-0.025^{*} \\
(0.013)\end{array}$ \\
\hline REQ2*FROA & $\begin{array}{l}-0.004 \\
(0.006)\end{array}$ & $\begin{array}{c}0.001 \\
(0.011)\end{array}$ \\
\hline REQ1*FLIQA & $\begin{array}{l}-0.006^{*} \\
(0.003)\end{array}$ & $\begin{array}{l}-0.006 \\
(0.003)\end{array}$ \\
\hline REQ2*FLIQA & $\begin{array}{l}-0.004 * \\
(0.002)\end{array}$ & $\begin{array}{l}-0.004 \\
(0.002)\end{array}$ \\
\hline REQ1*FSALES & $\begin{array}{c}0.002 \\
(0.002)\end{array}$ & $\begin{array}{c}0.000 \\
(0.003)\end{array}$ \\
\hline REQ2*FSALES & $\begin{array}{l}-0.003 \\
(0.003)\end{array}$ & $\begin{array}{l}-0.005 \\
(0.003)\end{array}$ \\
\hline BPCPR & $\begin{array}{c}0.001 \\
(0.003)\end{array}$ & $\begin{array}{c}0.002 \\
(0.003)\end{array}$ \\
\hline MBANK & $\begin{array}{l}0.583^{* *} \\
(0.022)\end{array}$ & $\begin{array}{l}0.573^{* *} \\
(0.021)\end{array}$ \\
\hline MBLFD & $\begin{array}{c}0.008 \\
(0.004)\end{array}$ & $\begin{array}{l}0.021^{* *} \\
(0.006)\end{array}$ \\
\hline MBPCPR & $\begin{array}{l}-0.002 \\
(0.001)\end{array}$ & $\begin{array}{l}-0.001 \\
(0.001)\end{array}$ \\
\hline KEIR & $\begin{array}{c}0.070 \\
(0.043)\end{array}$ & $\begin{array}{c}0.068 \\
(0.047)\end{array}$ \\
\hline PK & $\begin{array}{l}-0.006^{* *} \\
(0.002)\end{array}$ & $\begin{array}{l}-0.006^{* *} \\
(0.002)\end{array}$ \\
\hline SAMEK & $\begin{array}{l}0.345 * * \\
(0.032)\end{array}$ & $\begin{array}{l}0.357^{* *} \\
(0.032)\end{array}$ \\
\hline Number of Observations & 96565 & 94074 \\
\hline Log Likelihood & -52083 & -50673 \\
\hline
\end{tabular}

Notes: The estimated equations also include FLASSET, FENBMKT, FINBMKT, FEXBMKT, a set of industry dummy variables, and a set of annual dummy variables. Below each estimated coefficient, we report the associated robust standard error calculated by relaxing the assumption of independence of the errors for a given year.

* Significant at the 5 percent level.

** Significant at the 1 percent level. 


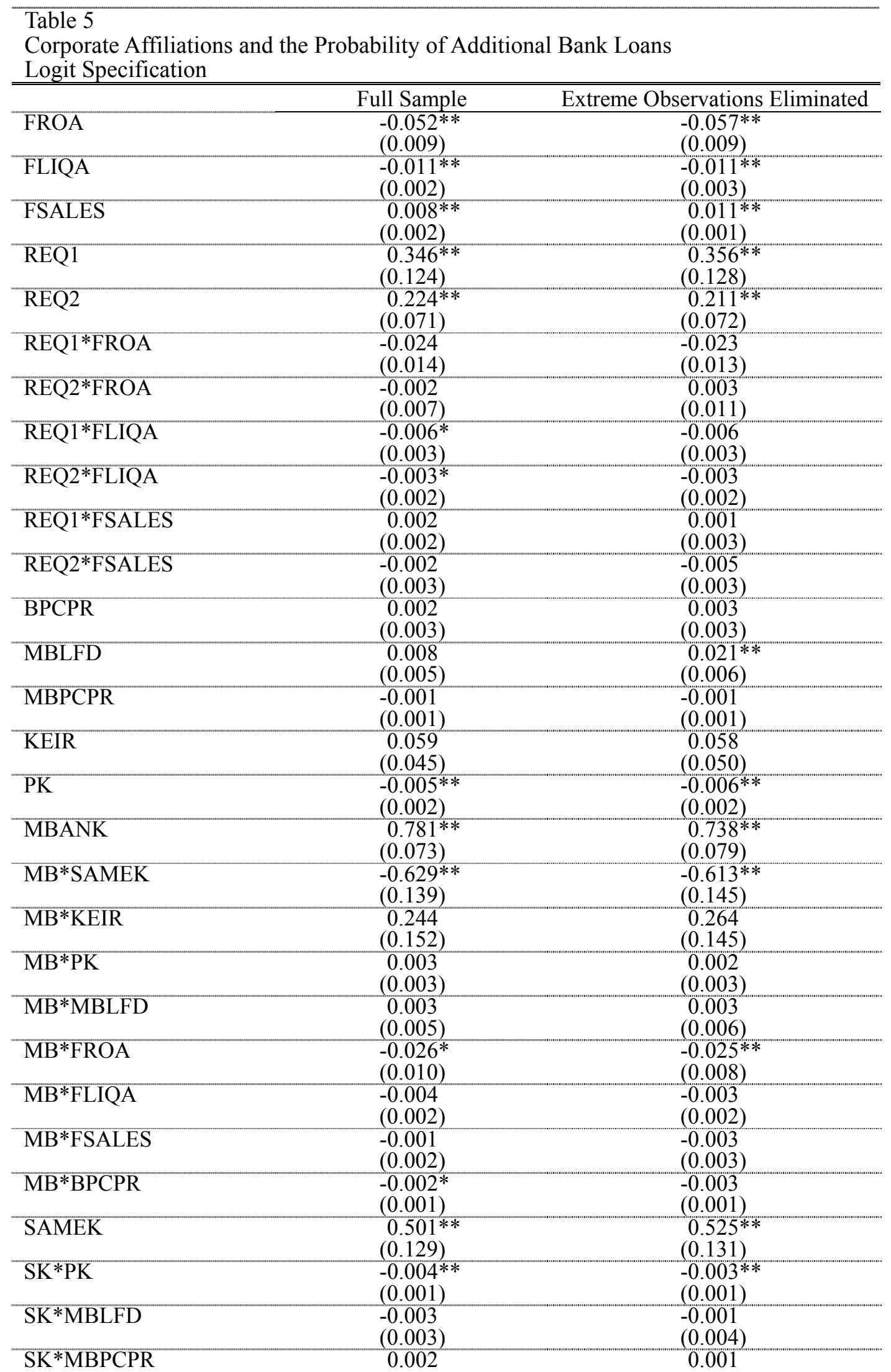




\begin{tabular}{lcc}
\hline & $(0.001)$ & $(0.001)$ \\
\hline SK*FROA & -0.001 & -0.006 \\
& $(0.014)$ & $(0.013)$ \\
\hline SK*FLIQA & 0.002 & 0.001 \\
& $(0.003)$ & $(0.002)$ \\
\hline SK*FSALES & $-0.007^{*}$ & $-0.007^{*}$ \\
& $(0.003)$ & $(0.003)$ \\
\hline SK*BPCPR & $-0.005^{*}$ & -0.004 \\
& $(0.002)$ & $(0.002)$ \\
\hline Number of Observations & 96565 & 94074 \\
\hline Log Likelihood & -52040 & -50635 \\
\hline \hline
\end{tabular}

Notes: The estimated equations also include FLASSET, FENBMKT, FINBMKT, FEXBMKT, a set of industry dummy variables, and a set of annual dummy variables. The set of estimated coefficients for secondary banks not in the same keiretsu is the base, with the estimated coefficients for all other types of lenders representing differential effects. Below each estimated coefficient, we report the associated robust standard error calculated by relaxing the assumption of independence of the errors for a given year.

* Significant at the 5 percent level.

** Significant at the 1 percent level. 


\begin{tabular}{|c|c|c|c|c|c|c|c|}
\hline $\begin{array}{l}\text { Table } 6 \\
\text { Factors Affecting the Pr } \\
\text { Logit Specification; Om }\end{array}$ & $\begin{array}{l}\text { ility of In } \\
\text { Extreme }\end{array}$ & $\begin{array}{l}\text { sed Lendin } \\
\text { servations }\end{array}$ & у Туре & ender & & & \\
\hline & $\begin{array}{c}\text { Main Bank } \\
\text { Same K }\end{array}$ & $\begin{array}{l}\text { Main Bank } \\
\text { Not same K }\end{array}$ & $\begin{array}{c}\text { Secondary } \\
\text { Same K }\end{array}$ & $\begin{array}{c}\text { Secondary } \\
\text { Not same K }\end{array}$ & $\begin{array}{c}\text { Nonbank } \\
\text { Same K }\end{array}$ & $\begin{array}{c}\text { Nonbank } \\
\text { Not same K }\end{array}$ & Government \\
\hline Intercept & $\begin{array}{c}0.299 \\
(0.261)\end{array}$ & $\begin{array}{c}0.275 \\
(0.245)\end{array}$ & $\begin{array}{l}-0.064 \\
(0.323)\end{array}$ & $\begin{array}{l}-0.696^{* *} \\
(0.225)\end{array}$ & $\begin{array}{l}-0.261 \\
(0.320)\end{array}$ & $\begin{array}{l}-0.950 * * \\
(0.313)\end{array}$ & $\begin{array}{l}-0.961 * * \\
(0.282)\end{array}$ \\
\hline FROA & $\begin{array}{l}-0.090^{* *} \\
(0.025)\end{array}$ & $\begin{array}{l}-0.097 * * \\
(0.009)\end{array}$ & $\begin{array}{l}-0.074^{* *} \\
(0.017)\end{array}$ & $\begin{array}{l}-0.061 * * \\
(0.011)\end{array}$ & $\begin{array}{l}-0.063^{*} \\
(0.026)\end{array}$ & $\begin{array}{l}-0.016 \\
(0.010)\end{array}$ & $\begin{array}{l}-0.045^{* *} \\
(0.012)\end{array}$ \\
\hline FLIQA & $\begin{array}{l}-0.011^{*} \\
(0.005)\end{array}$ & $\begin{array}{l}-0.018^{* *} \\
(0.003)\end{array}$ & $\begin{array}{l}-0.012^{* *} \\
(0.003)\end{array}$ & $\begin{array}{l}-0.011 * * \\
(0.003)\end{array}$ & $\begin{array}{l}-0.006^{*} \\
(0.003)\end{array}$ & $\begin{array}{l}-0.005 \\
(0.004)\end{array}$ & $\begin{array}{l}-0.010^{* *} \\
(0.003)\end{array}$ \\
\hline FSALES & $\begin{array}{l}-0.000 \\
(0.007)\end{array}$ & $\begin{array}{c}0.005 \\
(0.004)\end{array}$ & $\begin{array}{c}0.001 \\
(0.003)\end{array}$ & $\begin{array}{c}0.009^{* *} \\
(0.002)\end{array}$ & $\begin{array}{l}0.008^{*} \\
(0.003)\end{array}$ & $\begin{array}{c}0.007 \\
(0.005)\end{array}$ & $\begin{array}{c}0.003 \\
(0.003)\end{array}$ \\
\hline KEIR & & $\begin{array}{c}0.449 * * \\
(0.133)\end{array}$ & & $\begin{array}{c}0.007 \\
(0.041)\end{array}$ & & $\begin{array}{c}0.383^{* *} \\
(0.140)\end{array}$ & $\begin{array}{l}0.410^{* *} \\
(0.081)\end{array}$ \\
\hline PK & $\begin{array}{l}-0.005^{*} \\
(0.002)\end{array}$ & $\begin{array}{l}-0.008 \\
(0.004)\end{array}$ & $\begin{array}{l}-0.009^{* *} \\
(0.003)\end{array}$ & $\begin{array}{l}-0.005^{* *} \\
(0.002)\end{array}$ & $\begin{array}{l}-0.012^{* *} \\
(0.003)\end{array}$ & $\begin{array}{l}-0.012^{*} \\
(0.005)\end{array}$ & $\begin{array}{l}-0.008^{* *} \\
(0.003)\end{array}$ \\
\hline MBLFD & $\begin{array}{c}0.020 \\
(0.011)\end{array}$ & $\begin{array}{l}0.029^{* *} \\
(0.005)\end{array}$ & $\begin{array}{l}0.026^{* *} \\
(0.007)\end{array}$ & $\begin{array}{l}0.022^{* *} \\
(0.007)\end{array}$ & $\begin{array}{c}0.011 \\
(0.009)\end{array}$ & $\begin{array}{c}0.005 \\
(0.007)\end{array}$ & $\begin{array}{l}-0.008 \\
(0.006)\end{array}$ \\
\hline MBPCPR & $\begin{array}{l}-0.004 \\
(0.002)\end{array}$ & $\begin{array}{l}-0.002 \\
(0.002)\end{array}$ & $\begin{array}{l}-0.001 \\
(0.002)\end{array}$ & $\begin{array}{c}0.000 \\
(0.001)\end{array}$ & $\begin{array}{l}-0.008^{* *} \\
(0.003)\end{array}$ & $\begin{array}{l}-0.002 \\
(0.003)\end{array}$ & $\begin{array}{l}-0.004^{*} \\
(0.002)\end{array}$ \\
\hline Number of Observations & & & & 142518 & & & \\
\hline Log Likelihood & & & & -74864 & & & \\
\hline
\end{tabular}

Notes: The estimated equations also include FLASSET, FENBMKT, FINBMKT, FEXBMKT, a set of industry dummy variables, and a set of annual dummy variables. Below each estimated coefficient, we report the associated robust standard error calculated by relaxing the assumption of independence of the errors for a given year.

* Significant at the 5 percent level.

** Significant at the 1 percent level. 
1 That Japanese banks have duties other than to maximize profits is made clear by the banking laws that require new investors and current owners with more than 20 percent ownership in a bank to obtain regulatory approval, including satisfying a condition that large shareholders "fully understand a bank's social responsibilities" (The Economist 2002b).

${ }^{2}$ The continuing deterioration in real estate prices, and of the Japanese economy more generally, resulted in lowered bank ratings, as well as the failure of some banks, and significant increases in the Japan premium, the additional risk premium Japanese banks paid in the interbank lending market (Peek and Rosengren 2001).

${ }^{3}$ A bank must classify a loan as nonperforming when the borrower has failed to make interest payments for more than three months, the loan is restructured, or the firm declares bankruptcy.

${ }^{4}$ In fact, some banks have even gone to the extreme of taking on loans called in by other banks, for example, Dai-ichi Kangyo Bank with Mycal loans, or buying loans from Shinsei Bank to avoid a repeat of the Sogo bankruptcy keyed in part by Shinsei putting its Sogo loans back to the government. Thus, these banks would be increasing their own exposure to severely troubled firms in order to delay inevitable bankruptcies by their borrowers.

${ }^{5}$ For example, it appears that almost half of the public funds injected into the banking system in 1998 and 1999 was used to provide debt forgiveness to construction companies (Tett and Ibison 2001). Such pressures have come out into the open recently with reports that Shinsei Bank, perhaps the only bank in Japan that has seriously applied credit risk analysis in its lending decisions, has been pressured by the FSA to continue lending to severely troubled firms, with FSA Commissioner Shoji Mori quoted as saying, "Shinsei should behave in line with other Japanese banks" (Singer and Dvorak 2001).

${ }^{6}$ For example, a study by the Nikkei newspaper found that nearly 75 percent of loans to Japanese firms that declared bankruptcy in 2000 had been classified as sound or merely in need of monitoring (The Economist 2001). And there is much evidence of government complicity with banks in the understatement of problem loans. For example, the put options granted to Shinsei and Aozora associated with the purchases of supposedly cleaned up banks were awarded to the buyers of the failed banks because the government prevented the bidders from inspecting the banks' books so that the exposures of other banks with loans to the same firms would not be exposed (The Economist 2002b).

${ }^{7}$ Certainly, banks do make risky loans. The key issue is whether banks are charging an appropriate risk premium to compensate them for the risk exposure. However, the evidence is that Japanese banks, for the most part, were not charging differential interest rates tied to the riskiness of loans. In fact, the evidence in both Tables 1 and 2 suggests that firms were leaving the bond market, an arms length market where they would be charged an appropriate risk premium, and returning to relationship loans from banks, and, furthermore, that firms receiving 
additional bank loans in the late 1990s had stock prices that tended to underperform the market during the subsequent year.

${ }^{8}$ For example, Bank of Japan Governor Masaru Hayami told parliament that the capital ratios of Japanese banks in March 2001 would have been only 7 percent rather than the reported 11 percent had they been held to the U.S. standards of capital adequacy (Dvorak 2001). An even lower, and likely more prudent, estimate of the state of capitalization of Japanese banks is that the reported 10 percent capital ratios of the big banks represents a capital ratio of only about 2 percent once the public funds injected into the banks, the value of deferred taxes, and the "profits" from the revaluation of real estate holdings are subtracted from the banks' capital (The Economist 2002).

${ }^{9}$ The reported regressions do not include FPCPR, since it was dominated as a measure of firm health by the other measures, never having a significant estimated coefficient. This may not be surprising, since once a Japanese firm's health has deteriorated substantially, its stock price movements are often dominated by news concerning the likelihood that the firm's lenders will rescue (bailout) the firm and the magnitude of any assistance the firm is likely to receive from its lenders, rather than the firm's own economic performance.

${ }^{10}$ This is not surprising, given the widely held views that bank capital ratios in Japan are substantially overstated and that the nonperforming loan ratios substantially understate the severity of the deterioration in the quality of loans in bank portfolios. To the extent that analysts are able to penetrate the veil of reported capital and nonperforming loan ratios, stock prices should reflect the best estimates of bank health.

${ }^{11}$ Extreme observations are defined as those for which any one of the regressors, other than the $(0,1)$ dummy variables, has a value that is more than four standard deviations from its mean value. The removal of observations with extreme values reduces the sample size by about 3 percent.

12 Although not shown in the table in order to conserve space, each regression includes a measure of firm size, a set of three bond market variables, a set of annual dummy variables, and a set of industry dummy variables, as described above. The logarithm of the firm's real assets always has a significant negative estimated coefficient, both here and in later specifications. Among the bond market variables, the dummy variable that has a value of one when a firm enters the bond market always has a significant negative estimated coefficient, as would be expected. Similarly, the dummy variable that has a value of one when a firm exits the bond market always has a significant positive estimated coefficient, as would be expected.

${ }^{13}$ It appears that the FSA may be getting tougher on banks, given the results of the recent FSA inspections of banks and their problem borrowers. Based on the inspections, 34 of the 149 firms were reclassified as being "in danger of bankruptcy," requiring banks to make loan loss provisions equal to 70 percent of the value of the loans rather than only 15 percent for loans "in need of monitoring." As a result, banks have had to substantially increase their loan loss 
provisions. However, the required provisions still were not large enough to reduce the capital ratios of any of the top 13 financial institutions below the required capital ratio (Pilling 2002). 